\title{
Energy Management Improving the Cooling System in a Local Factory
}

\author{
ENG. Moath Abdrabu Eldbari ${ }^{1}$, Muhammad N Radhwi ${ }^{1}$ \\ ${ }^{1}$ Umm Al-Qura University-Makkah-KSA \\ eng.medbari@gmail.com
}

\begin{abstract}
Development is an ongoing process in all areas and this research studied of a cooling system for a local factory and evaluated to determine the efficiency and capacity of the cooling capacity of the factory at the desired level. After evaluating the cooling system and studying the case of the local factory, the heat gain loads in the factory was calculated internally and externally and found that there is a deficit in the cooling system by $45 \%$ and the suggestion is to improve the cooling system without affecting production or manpower. Accordingly, three points have been developed to improve the cooling system and the first point is reducing the heat gained from lighting by changing fluorescent bulbs by the LED and this step will reduce the heat gain from lighting by $64 \%$. The second point is to reduce the volume space of production zones by installing the ceiling of the gypsum board where the height was reduced from eight to five meters, which reduced the heat gained by $37 \%$ from the walls. The third point is the installation of better insulation materials and has been proposed rock wool material for the roof and the material Rigid expanded board for walls and these materials have reduced $85 \%$ of the heat gain from the roof and $20 \%$ of the walls. The total rate of improvement in the cooling system completely (internal and external heat gain) is $25 \%$ or in other words, can be through the implementation of these points reduce cooling load by $25 \%$.
\end{abstract}

Keywords: energy; management; cooling system; local factory.

\section{Introduction}

Energy consumption in industry is considered a key factor in the industrial process, especially in heat treatment manufacturing industries so these industries tend to use highly efficient energy sources such as gas and fuel instead of electricity because of the efficiency of the conversion of thermal energy from oil derivatives is much higher than the conversion from electricity. However, the cooling system still relies mainly on electric power and at the same time, the cooling system is an essential system in the industry to provide a suitable working environment for employees first and products and production lines second.

A local factory working in the printing and packaging sector needs a working environment with specific standards such as temperature, humidity, ventilation, etc. These standards are important to ensure that products of the required quality are obtained because of the effects of the above elements on packaging material, paper, inks, etc. The work environment standards are no longer achieved as temperatures exceed 35 degrees and humidity exceeds $80 \%$, which causes problems in the quality of products, in addition to the difficulty of working in such circumstances.

The factory has a cooling system but the COP is low and does not meet the required level and at the same time there is a constant rise in electricity bills compared to previous years where the temperature inside the factory exceed $38 \mathrm{C}^{\circ}$ in summer days and that affecting the operation processes and the quality of products. To Evaluate the cooling system we need to calculate the COP where we have 24 package units in the system, the below is an example of how to calculate the COP (Cengel \& Boles, 2007).

COP cooling $=\frac{Q_{\text {out }}}{W_{\text {in }}} \quad$ or 
COP cooling $=\frac{T_{\text {out }}}{T_{\text {in }}-T_{\text {out }}}$

Where $T_{\text {in }}=\mathrm{T}$ entering the cooling system $\left(45 C^{\circ}\right), T_{\text {out }}=T$ out of the system COP $P_{\text {cooling }}=\frac{33 C^{\circ}}{45 C^{\circ}-33 C^{\circ}}=2.75 C O P$

Table 1. List of Package units and their COP

\begin{tabular}{|c|c|c|}
\hline Unit & $T_{\text {out }}$ & COP \\
\hline 1 & 33 & 2.75 \\
\hline 2 & 35 & 3.5 \\
\hline 3 & 27 & 1.5 \\
\hline 4 & 22 & 0.96 \\
\hline 5 & 22 & 0.96 \\
\hline 6 & 30 & 2.00 \\
\hline 7 & 35 & 3.50 \\
\hline 8 & 38 & 5.43 \\
\hline 9 & 38 & 5.43 \\
\hline 10 & 31 & 2.21 \\
\hline 11 & 29 & 1.81 \\
\hline 12 & 29 & 1.81 \\
\hline 13 & 30 & 2 \\
\hline 14 & 0 & 0 \\
\hline 15 & 31 & 2.21 \\
\hline 16 & 0 & 0 \\
\hline 17 & 0 & 0 \\
\hline 18 & 0 & 0 \\
\hline 19 & 0 & 0 \\
\hline 20 & 0 & 0 \\
\hline 21 & 0 & 0 \\
\hline 22 & 0 & 0 \\
\hline 23 & 28 & 1.65 \\
\hline 24 & 0 & 0 \\
\hline
\end{tabular}

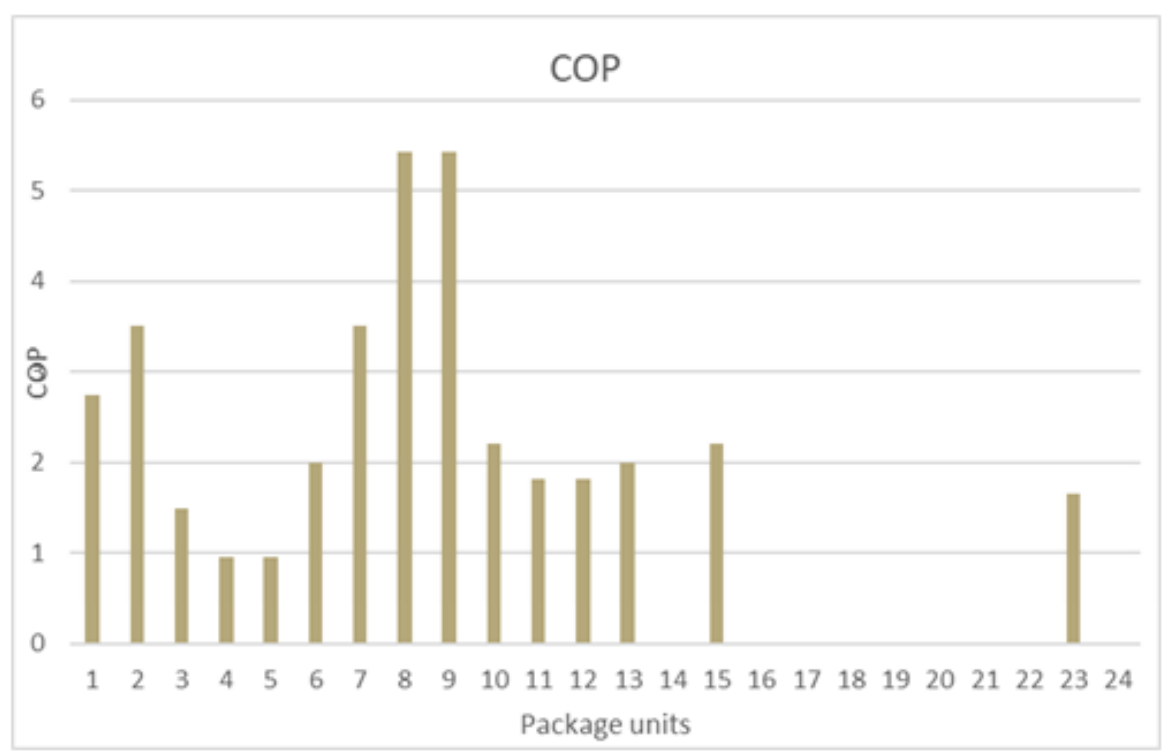

Figure 1. Chart of COP for cooling units 


\section{AC capacity in the factory:}

The current capacity of cooling system in the local factory is 260 ton and it was more than 15 years since they installed. The condition of the package unit is vary from one to another but in general the condition of most of them is very poor and Table 2 illustrates the capacity types of package units and the quantity as in Table 3 shows the condition of these units.

Table 2. Capacity of cooling system and number of unit

\begin{tabular}{|c|c|}
\hline AC Capacity & Quantity \\
\hline 5 Ton & 10 \\
\hline 10 Ton & 7 \\
\hline 20 Ton & 7 \\
\hline Total = 260 Ton & Total units $=24$ unit \\
\hline
\end{tabular}

Table 3. Status of cooling system units

\begin{tabular}{|c|c|c|}
\hline Total Unit & Working Unit & Breakdown Unit \\
\hline 24 unit & 15 unit & 9 unit \\
\hline
\end{tabular}

The package units were distributed in the local factory as shown in figure 13 where the cooling ducts separate the cooling air in production areas.

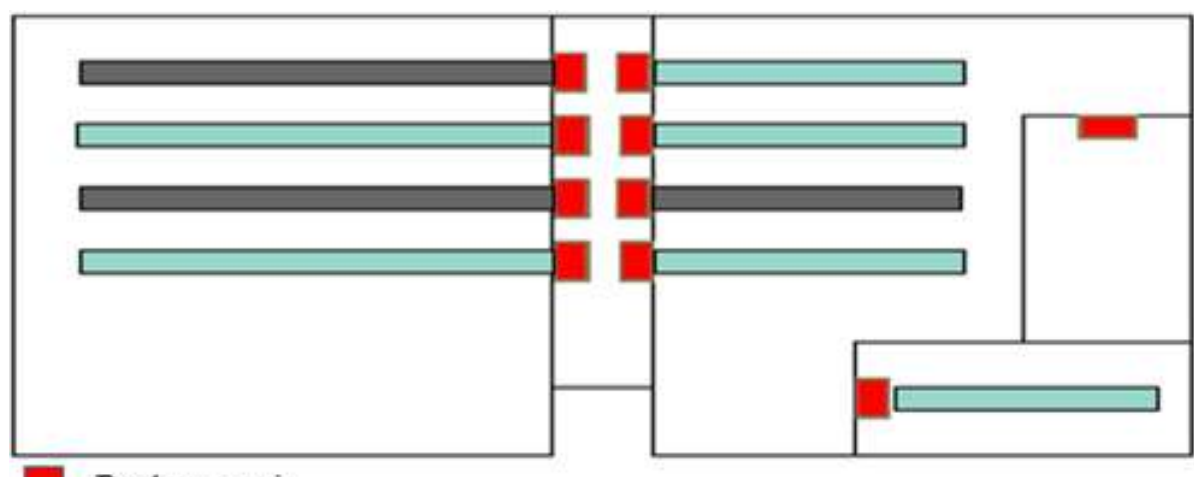

\section{Package unit}

Working cooling line

Not working cooling line

Figure 2. The Package unit working conditions

There are three types of machines about heat source: machines produce high heat, medium heat and low heat. All these types are available in the local factory and located as shown in Figure 3.

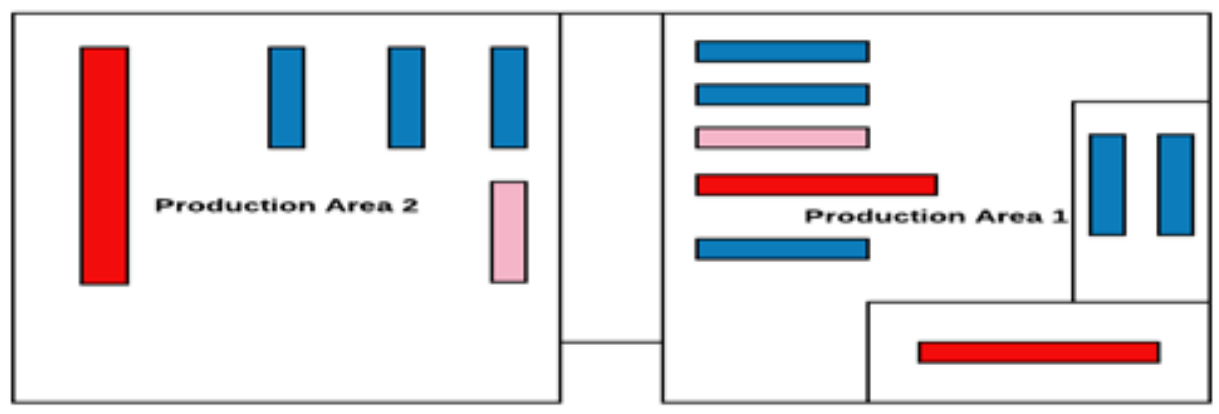




\section{Machines produce high heat \\ Machines produce medium heat \\ Machines produce low heat}

Figure 3. Schematic diagram for machines location and their types

In this paper, we will study the heat gain sources in the local plant and the current design of the cooling system, then study the applied methods to improve the cooling system by reducing the cooling load in the factory. The management of the factory is considering replacing the current cooling system, because of its poor performance and high energy consumption, as well as its inability to produce the required results as shown in figure 1 and table 1, which necessitated the work of this research to solve this problem.

Table 2 shows the current cooling system capacity during the last 15 years (the time of installation of the current cooling system), the number of employees in the factory has increased and the number of production lines has increased without any noticeable development in the cooling system and figures 2 and 3 illustrate the locations of the machines and cooling system in the local factory. The aim of this research is not to elaborate on engineering theories and equations on the subject of cooling as much as we want to solve the problem by engineering methods this means that the focus of the research will be on reducing cooling loads of the factory.

\section{Research Methods}

\section{Analysis and Calculations}

In the beginning, we need to know the terms in cooling systems such as Heat gain is the rate of heat generated in the system or transmitted to it. Cooling load, which is the rate of energy to be removed from the system to maintain the temperature and humidity at the required level (McQuiston et al, 2005).

\section{Calculation of current cooling loads:}

To calculate cooling loads, heat gain from outside the system and heat generated in it must be calculated, in other words internal heat gain and external heat gain. The internal heat gained can be divided into three elements: people, lighting and equipment. The internal heat gain is the most effective on the cooling system the next step is calculations of internal and external heat gain.

\section{Internal Heat gain: People:}

There are two types of heat gained from people: sensible and latent heat. Sensible heat is the heat transfer from the human body to the air where the human body about $37^{\circ} \mathrm{C}$ and the air which is around $25-23^{\circ} \mathrm{C}$ and because of the difference between temperatures the heat transfer occur. People also release latent heat due to evaporation of water vapor with breathing and sweating form skin to the air. According to ASHREA sensible and latent heat for adults can be found in categories in the manual where it divided the categories according to the activities as shown in table 4 (ASHRAE, 1992).

The sensible temperature released by people is defined in the equation (Bhatia, 2001): 


$$
Q_{p s}=\mathrm{N} * q_{p s} * \text { (D.F) }
$$

The latent temperature released by people is defined in the equation (Bhatia, 2001):

$$
Q_{p l}=\mathrm{N} * q_{p l} *(D . F)
$$

Where:

$Q_{p s}=$ People sensible temperature.

$Q_{p l}=$ People latent temperature

$N=$ Number of people: ( 120 people are working in the local factory).

$q_{p s}=$ Sensible heat gain: (Table 4 ).

$q_{p l}=$ Latent heat gain: (Table 4).

$D . F=$ Diversity Factor. (Equal to 1$)$.

\section{Discussion}

\begin{tabular}{|c|c|c|c|c|c|c|c|c|c|}
\hline \multirow[b]{2}{*}{ Degree of Activity } & \multirow[b]{2}{*}{ Typical Application } & \multicolumn{2}{|c|}{$\begin{array}{l}\text { Total Heat } \\
\text { Adults, } \\
\text { Male }\end{array}$} & \multicolumn{2}{|c|}{$\begin{array}{l}\text { Total Heat } \\
\text { Adjusted }^{b}\end{array}$} & \multicolumn{2}{|c|}{$\begin{array}{c}\text { Sensible } \\
\text { Heat }\end{array}$} & \multicolumn{2}{|c|}{$\begin{array}{c}\text { Latent } \\
\text { Heat }\end{array}$} \\
\hline & & Btu/hr & w & Btu/hr & W & Btu/hr & W & Btu/hr & W \\
\hline Seated at theater & Theater-matinee & 390 & 114 & 330 & 97 & 225 & 66 & 105 & 31 \\
\hline Seated at theater & Theater-evening & 390 & 114 & 350 & 103 & 245 & 72 & 105 & 31 \\
\hline $\begin{array}{l}\text { Seated, very light } \\
\text { work }\end{array}$ & $\begin{array}{l}\text { Offices, hotels, } \\
\text { apartments }\end{array}$ & 450 & 132 & 400 & 117 & 245 & 72 & 155 & 45 \\
\hline $\begin{array}{l}\text { Moderately active } \\
\text { office work }\end{array}$ & $\begin{array}{l}\text { Offices, hotels, } \\
\text { apartments }\end{array}$ & 475 & 139 & 450 & 132 & 250 & 73 & 200 & 59 \\
\hline $\begin{array}{l}\text { Standing. light work; } \\
\text { walking }\end{array}$ & $\begin{array}{l}\text { Department store, } \\
\text { retail store }\end{array}$ & 550 & 162 & 450 & 132 & 250 & 73 & 200 & 59 \\
\hline Walking: standing & Drugstore, bank & 550 & 162 & 500 & 146 & 250 & 73 & 250 & 73 \\
\hline Sedentary work & Restaurant & 490 & 144 & 550 & 162 & 275 & 81 & 275 & 81 \\
\hline Light bench work & Factory & 800 & 235 & 750 & 220 & 275 & 81 & 475 & 139 \\
\hline Moderate dancing & Dance hall & 900 & 264 & 850 & 249 & 305 & 89 & 545 & 160 \\
\hline $\begin{array}{l}\text { Walking } 3 \text { mph: light } \\
\text { machine work }\end{array}$ & Factory & 1000 & 293 & 1000 & 293 & 375 & 110 & 625 & 183 \\
\hline Bowling ${ }^{d}$ & ag alley & 1500 & 440 & 1450 & 425 & 580 & 170 & 870 & 255 \\
\hline Heavy work & Factory & 1500 & 440 & 1450 & 425 & 580 & 170 & 870 & 255 \\
\hline $\begin{array}{l}\text { Heavy machine } \\
\text { work: lifting }\end{array}$ & Factory & 1600 & 469 & 1600 & 469 & 635 & 186 & 965 & 283 \\
\hline Athletics & Gymnasium & 2000 & 586 & 1800 & 528 & 710 & 208 & 1090 & 320 \\
\hline
\end{tabular}

Table 4. Rates of heat gain from occupants according to activities (ASHRAE, 1992).

The results are:

$$
\begin{aligned}
& Q_{p s}=120 \times 90 \times 1=20.4 \mathrm{KW} \\
& Q_{p l}=120 \times 160 \times 1=30.6 \mathrm{KW} \\
& Q_{P . \text { total }}=Q_{p s}+Q_{p l}=51 \mathrm{KW}
\end{aligned}
$$

\section{Lighting:}

Lighting is one of the major internal loads, especially in industry, the more complex the activity is strong lighting is required (McQuiston et al, 2005) and the equation of calculating the heat gain from light is: 
$Q_{L}=N * P * F * D F$

Where:

$\mathrm{N}=$ Number of bulbs ( 835 pieces)

$\mathrm{P}=$ The capacity of a bulb.

$\mathrm{F}=$ Factor (1.25 -1.30 for florescent lamps- 1.0 for bulb lamp).

$\mathrm{DF}=$ Diversity Factor.

Types of light that available in the local factory is fluorescent tubes lamps and the details as below:

$\mathrm{N}=835$ Lamps.

$\mathrm{P}=36 \mathrm{w} /$ lamp.

$\mathrm{F}=1.25$

$Q_{L}=835 \times 36 \times 1.25 \times 1=36 \mathrm{~kW}$.

\section{Equipment:}

The machines vary in the generation the heat gain, some contain machines have mechanical systems and some contain furnaces or heating systems, which increases the heat gain rate. The following equation to calculate the heat gain from the equipment in the factory and because of huge number of machines the table 5 has a results of heat gain from machines with function and quantity of each type (Bhatia, 2001., Janna, 2013):

Where:

$$
Q_{E}=\sum(1-?) E
$$

$Q_{E}=$ Heat of equipment.

? = Motor capacity.

$E=$ Motor efficiency.

Table 5. Machines heat load in the factory

\begin{tabular}{|c|c|c|}
\hline Quantity & Machines & Load (Kw) \\
\hline 1 & Sheeting & 37 \\
\hline 5 & Offset Printing & 278 \\
\hline 2 & Die Cutting & 36 \\
\hline 2 & Folding and Gluing & 30 \\
\hline 5 & Folding & 89 \\
\hline 2 & UV Coating & 95 \\
\hline 4 & Slitting & 63 \\
\hline 2 & Label Printing & 205 \\
\hline 1 & WEB Printing & 225 \\
\hline
\end{tabular}

The summation of equipment loads is:

$Q_{E}=1058 \mathrm{KW}$

Total Internal Heat Gain is:

$Q_{\text {Internal heat gain }}=Q_{P . \text { total }}+Q_{L}+Q_{E}=1145 \mathrm{KW}$ 


\section{External Heat gain:}

External heat gain is the loads that are transferred to the building by walls, roofs or floor through by conduction or through windows and glass roofs by radiation (McQuiston et al, 2005, Bhatia, 2001).

This is calculations of four walls (south, east, north and West) and roof before improvement.

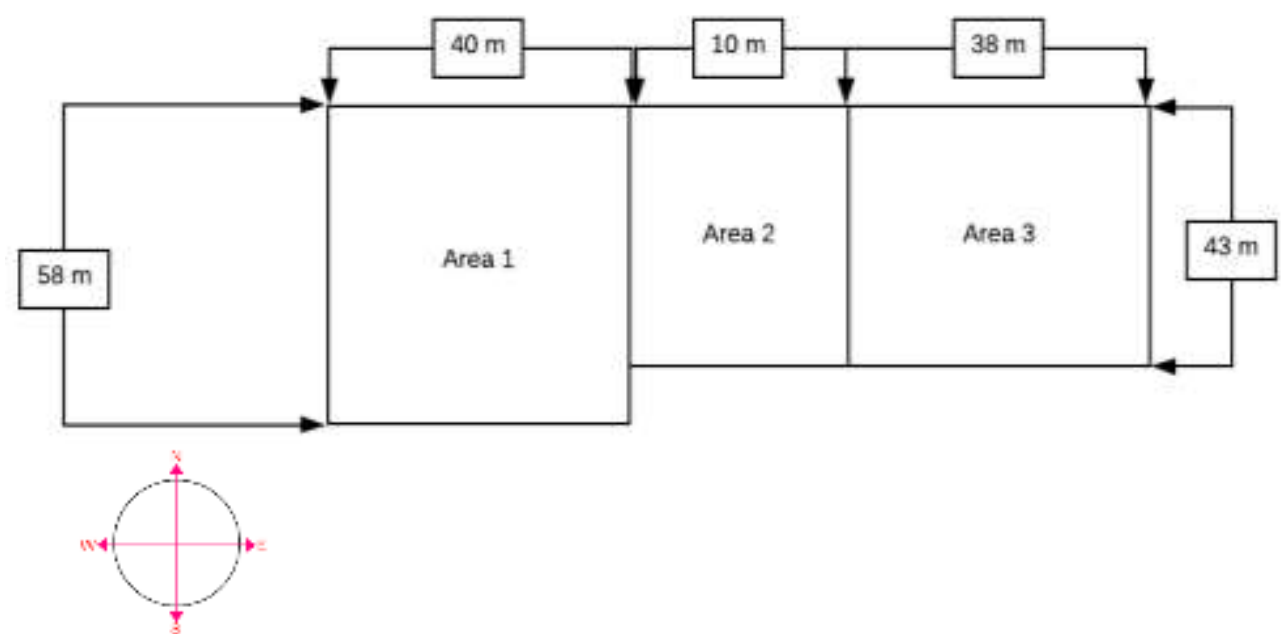

Figure 4. Schematic diagram for factory areas and walls location

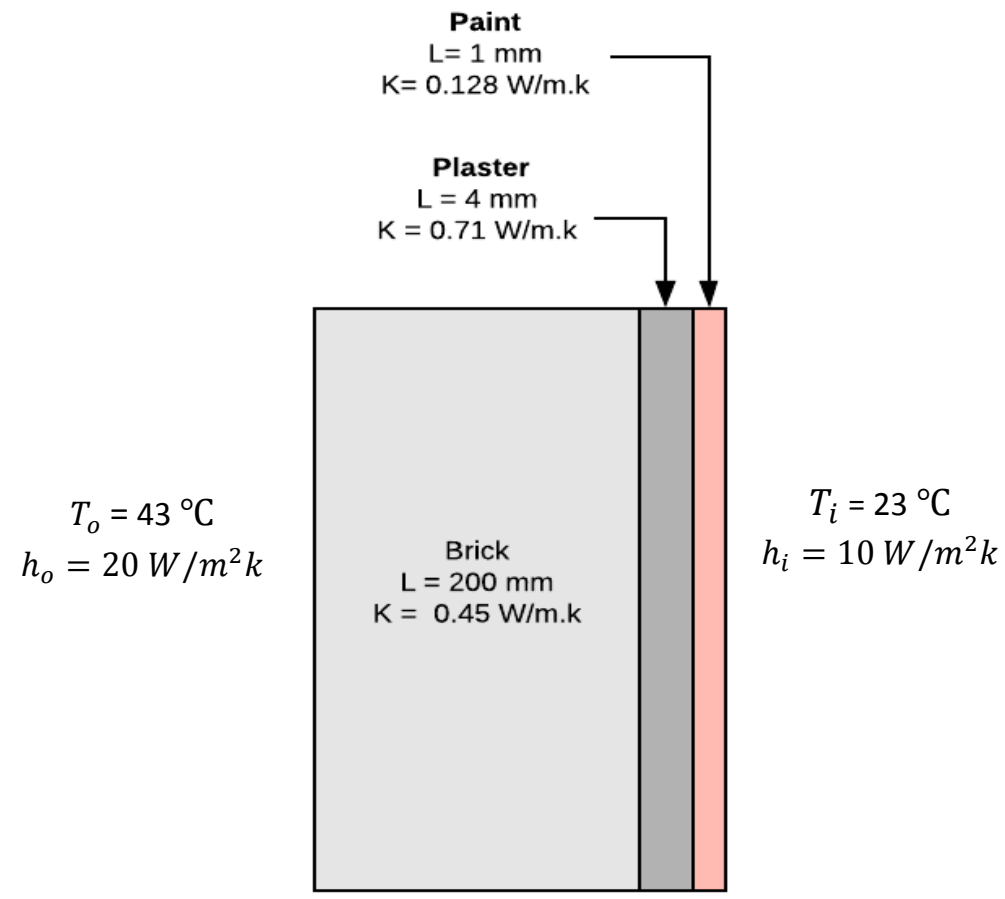

Figure 5. Schematic diagram for wall components and air specifications inside

\section{South wall calculation}

$\mathrm{U}=\frac{1}{R_{t}}, \mathrm{R}=\frac{L}{k}, R_{t}=R_{1}+R_{2}+R_{3}+\cdots$ 
$R_{t}=R_{1}+R_{2}+R_{3}$

$R_{t}=\frac{0.2}{1.72}+\frac{0.004}{0.71}+\frac{0.001}{0.128}=0.458 m^{2} \mathrm{~K} / \mathrm{W}$

$U_{t}=\frac{1}{0.458}=2.184 \mathrm{~W} / \mathrm{m}^{2} \mathrm{~K}$

$\mathrm{A}=$ length $\mathrm{x}$ high $=88 \times 8=704 \mathrm{~m}^{2}$

$Q_{\text {South Wall }}=\mathrm{A} * \mathrm{U} * \Delta \mathrm{t}$

$Q_{\text {South Wall }}=704 \times 2.184 \times(43-23)=30.751 \mathrm{KW}$

\section{East wall calculation 1}

$R_{t}=\frac{0.2}{1.72}+\frac{0.004}{0.71}+\frac{0.001}{0.128}=0.458 m^{2} \mathrm{~K} / \mathrm{W}$

$U_{t}=\frac{1}{0.458}=2.184 \mathrm{~W} / \mathrm{m}^{2} \mathrm{~K}$

$A=$ length $\mathrm{x}$ high $=(43 \times 8)+(15 \times 8)=464 \mathrm{~m}^{2}$

$Q_{\text {East Wall }}=\mathrm{A} * \mathrm{U} * \Delta \mathrm{t}$

$Q_{\text {East Wall }}=464 \times 2.184 \times(43-23)=20.268 \mathrm{KW}$

\section{West wall calculation}

$R_{t}=\frac{0.2}{1.72}+\frac{0.004}{0.71}+\frac{0.001}{0.128}=0.458 \mathrm{~m}^{2} \mathrm{~K} / \mathrm{W}$

$U_{t}=\frac{1}{0.458}=2.184 \mathrm{~W} / \mathrm{m}^{2} \mathrm{~K}$

$\mathrm{A}=$ length $\mathrm{x}$ high $=58 \times 8=464 \mathrm{~m}^{2}$

$Q_{\text {West Wall }}=\mathrm{A} * \mathrm{U} * \Delta \mathrm{t}$

$Q_{\text {West Wall }}=464 \times 2.184 \times(43-23)=20.268 \mathrm{KW}$

\section{North wall calculation}

$R_{t}=\frac{0.2}{1.72}+\frac{0.004}{0.71}+\frac{0.001}{0.128}=0.458 m^{2} \mathrm{~K} / \mathrm{W}$

$U_{t}=\frac{1}{0.458}=2.184 \mathrm{~W} / \mathrm{m}^{2} \mathrm{~K}$

A = length $\mathrm{x}$ high $=88 \times 8=704 \mathrm{~m}^{2}$

$Q_{\text {North Wall }}=\mathrm{A} * \mathrm{U} * \Delta \mathrm{t}$

$Q_{\text {North Wall }}=704 \times 2.184 \times(43-23)=30.751 \mathrm{KW}$ 


\section{Roof calculation}

$$
\begin{gathered}
T_{o}=43^{\circ} \mathrm{C} \\
h_{o}=20 \mathrm{~W} / \mathrm{m}^{2} \mathrm{k}
\end{gathered}
$$

\begin{tabular}{|c|}
\hline Galvanized Iron $\mathrm{L}=1 \mathrm{~mm} \mathrm{~K}=60 \mathrm{~W} / \mathrm{m} . \mathrm{k}$ \\
\hline Polystyrebe Insulation $\mathrm{L}=20 \mathrm{~mm} \mathrm{~K}=0.042 \mathrm{~W} / \mathrm{m} . \mathrm{k}$ \\
$T_{i}=23^{\circ} \mathrm{C}$ \\
$h_{i}=10 \mathrm{~W} / \mathrm{m}^{2} \mathrm{k}$
\end{tabular}

Figure 6. Schematic diagram for Areas $1 \& 3$ roof components.

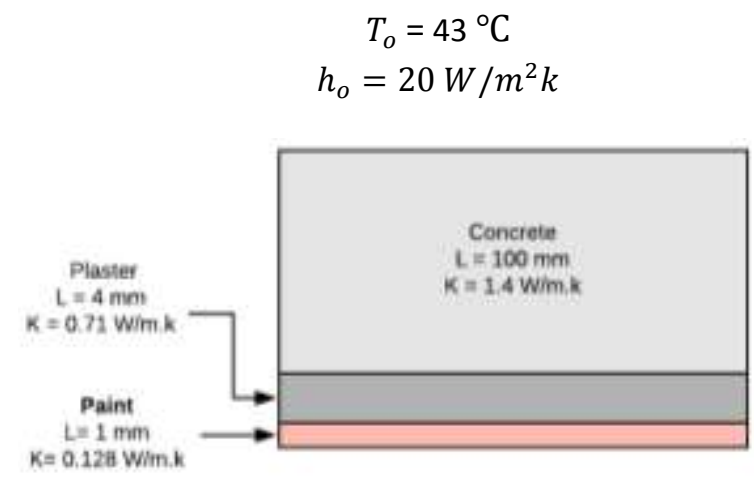

Figure 7. Schematic diagram for Areas 2 roof components.

\section{Roof calculation}

$$
\begin{aligned}
& \mathrm{U}=\frac{1}{R_{t}}, \mathrm{R}=\frac{L}{k}, \frac{1}{R_{1,2,3}}=\frac{1}{R_{1}}+\frac{1}{R_{2}}+\frac{1}{R_{3}}, R_{t}=R_{o}+R_{1,2,3}+R_{i} \\
& R_{\text {Area } 1,3}=R_{1}+R_{2}=\frac{0.001}{60}+\frac{0.02}{0.042}=0.476 \mathrm{~m}^{2} \mathrm{~K} / \mathrm{W} \\
& R_{\text {Area } 2}=R_{1}+R_{2}+R_{3}=\frac{0.100}{1.4}+\frac{0.004}{0.71}+\frac{0.001}{0.13}=0.0849 \mathrm{~m}^{2} \mathrm{~K} / \mathrm{W} \\
& \frac{1}{R_{\text {Area } 1,2,3}}=\frac{1}{0.476}+\frac{1}{0.0849}+\frac{1}{0.476}=15.98 \mathrm{~K} / \mathrm{W}, R_{\text {Area } 1,2,3}=\frac{1}{15.98}=0.0626 \mathrm{~m}^{2} \mathrm{~K} / \mathrm{W} \\
& R_{t}=\frac{1}{20}+0.0626+\frac{1}{10}=0.21258 \mathrm{~m}^{2} \mathrm{~K} / \mathrm{W} \\
& U_{t}=\frac{1}{0.21258}=4.704 \mathrm{~W} / \mathrm{m}^{2} \mathrm{~K}
\end{aligned}
$$


$A=$ length $*$ high $=[(58 \times 40)+(10 \times 43)+(38 \times 43)]=4384 \mathrm{~m}^{2}$

$Q_{R}=\mathrm{A} * \mathrm{U} * \Delta \mathrm{t}=4384 \times 4.704 \times(43-23)=412.45 \mathrm{KW}$

\section{Total load of walls and roof}

$Q_{\text {External heat gain }}=Q_{\text {South }}+Q_{\text {East }}+Q_{\text {West }}+Q_{\text {North }}+Q_{\text {Roof }}=514.5 \mathrm{KW}$

$Q_{\text {Total heat gain }}=Q_{\text {External heat gain }}+Q_{\text {Internal heat } \text { gain }}=1659.5 \mathrm{KW}$

Table 6. Loads of all four walls and roof before improvement

\begin{tabular}{|c|c|c|}
\hline Direction & Load Q & Load Q Value (KW) \\
\hline South & $Q_{S}$ & 30.75 \\
\hline East & $Q_{E}$ & 20.27 \\
\hline West & $Q_{W}$ & 20.27 \\
\hline North & $Q_{N}$ & 30.75 \\
\hline Roof & $Q_{R}$ & 412.45 \\
\hline Total & $Q_{\text {Total }}$ & 514.49 \\
\hline
\end{tabular}

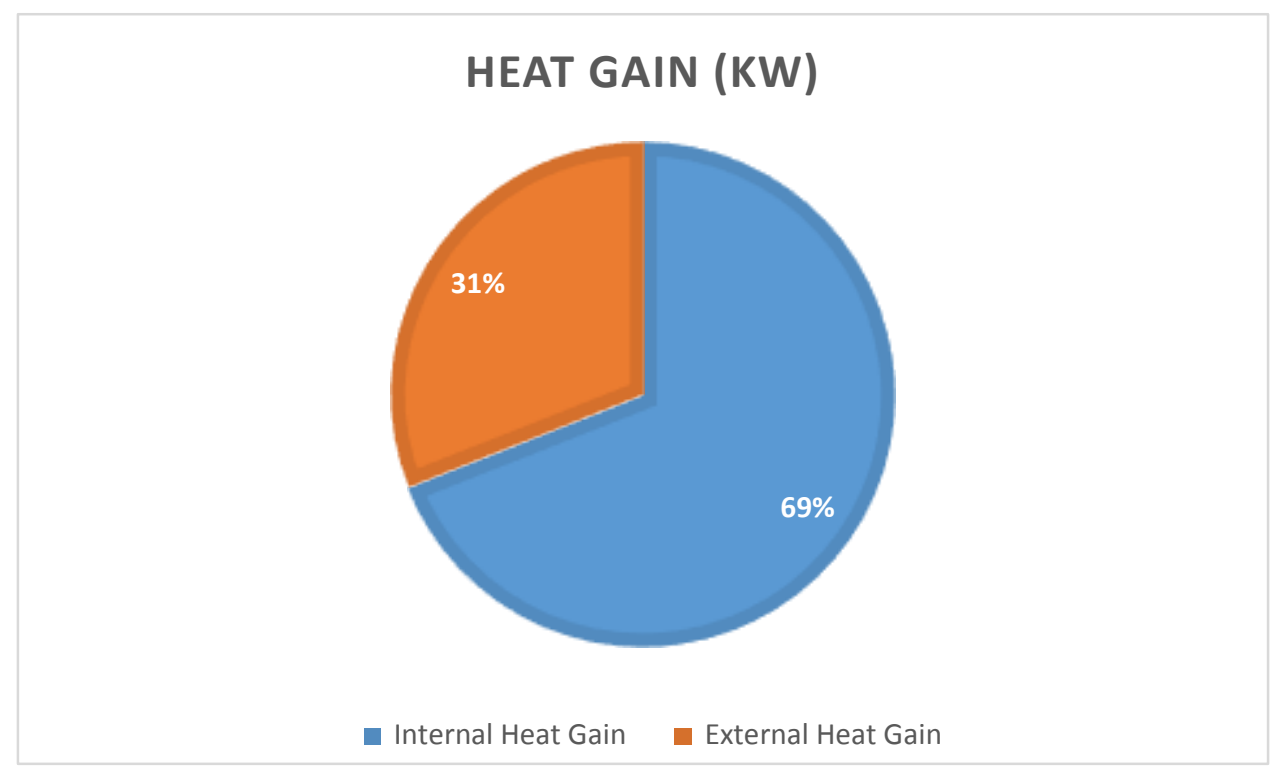

Figure 8. Diagram compares between internal and external heat gain.

In Figure 8 shows that the heat gain of people, lighting and equipment is much greater than the heat gain of the walls and the roof where the internal heat gain percentage is around $70 \%$ and the external heat gain about $30 \%$. Therefore, in is this case, we will study to make improvements to reduce the heat load and raise energy efficiency, which will be discussed later. Through the above equations and calculations, we can compare the capacity of the current cooling system with the heat loads in the factory and is this system sufficient to cool the factory 
or not? We will need to convert heat load from watts to tons of refrigeration through the relationship below and therefore the efficiency and capacity of the current cooling system of the local factory can be evaluated.
$1 \mathrm{KW}=3412 \mathrm{Btu} / \mathrm{hr}$
1 ton $=12000 \mathrm{Btu} / \mathrm{hr}$
Cooling loads required $=1659.5 \times 3412=5662214 \mathrm{Btu} / \mathrm{hr}$
Cooling loads required $=\frac{5662214}{12000}=471.9$ ton $($ Bhatia, 2001).

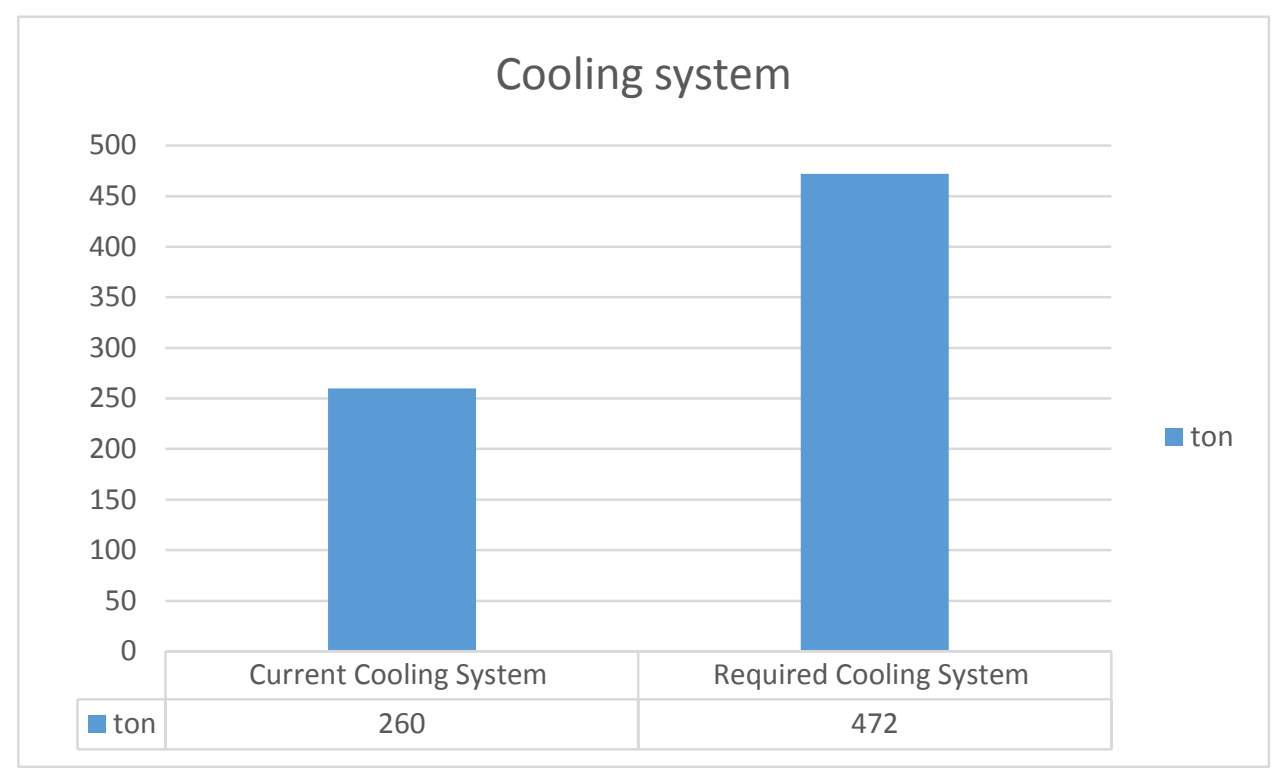

Figure 9. Diagram compares between current and required cooling system.

From the previous relationship and through the information gathered from the local factory there is a shortage of cooling capacity considerably as shown in figure 9 as the current cooling capacity is 260 ton but the required cooling capacity is 472 ton. The current cooling system is covering only $55 \%$ of the cooling required for the factory capacity if we assume that all cooling units currently in the factory are working well but not All units are functioning properly, as shown in table 3 and this gap in the capacity of the cooling system shows that the decision of the factory management to improve the cooling system was correct.

\section{Improving the cooling system:}

The researcher seeks to improve the efficiency of the cooling system by studying the research sample and trying to find solutions that can improve the cooling system, which will reflect on the energy efficiency and activate the role of energy management in this field. It is difficult to redesign the cooling system from scratch because the factory is working and it is part of supply chain of food and medicine industry and has a commitment to its customers, so the research focused on things that can be done in a way that does not interfere with the production lines. The objective of this study is to improve the cooling system by reducing cooling loads in the local factory and the study concluded that the elements that could be improved are:

- Improved lighting system. 
- Reduce the volume of the cooling space.

- Improve the insulation of walls and roof.

After studying the situation on the ground in the factory, the study concluded that applying the above improvements is appropriate to achieve the objectives of the study and at the same time does not cause a disturbance of the production process. In addition, the remaining elements such as people or equipment difficult to change because they are linked to other fields.

\section{Improving lighting system}

Industries have developed rapidly in the last two decades and this includes the lighting industry from traditional light bulbs to fluorescent and halogen to LED according to the National optical astronomy observatory (NOAO, 2019).

Table 1. Comparison between Fluorescent and LED lambs.

\begin{tabular}{|c|c|c|}
\hline & Fluorescent & LED \\
\hline Number of Bulb & 835 & 835 \\
\hline W & 36 & 13.6 \\
\hline Heat gain & $36 \mathrm{~kW}$ & $13.6 \mathrm{~kW}$ \\
\hline Saving ratio & \multicolumn{2}{|c|}{$64 \%$} \\
\hline
\end{tabular}

$\mathrm{N}=835$ Lamps.

$\mathrm{P}=36 \mathrm{w} /$ lamp.

$\mathrm{F}=1.25$

$Q_{L}=835 \times 13 \times 1.25 \times 1=13.6 \mathrm{~kW}$.

The factory has 835 fluorescent bulbs and the capacity of each 36 watts, which can be replaced by LED bulbs 13 watts and is about three times less in consumption which is $64 \%$ less as shown in table 6 above. Reducing lighting heat gain from $36 \mathrm{~kW}$ to $13 \mathrm{~kW}$ is a good step in improving the cooling system.

Total internal heat gain:

$Q_{\text {Internal heat gain }}=Q_{P . t o t a l}+Q_{L}+Q_{E}=1122.6 \mathrm{KW}$

\section{Reduce the volume of the cooling space:}

Reduce the size of the cooling space reduces heat gain by reducing the external walls area that exposed to the sun's rays will be done through the installation of the ceiling at a height of 5 meters to become the height of the inner wall of the production area of 5 meters instead of 8 as shown in figure 10 where that does not conflict with the space required for the production lines at the same time allows extensions of air-conditioning work smoothly and without obstacles. Install ceilings depends on the construction of steel structure capable of carrying gypsum boards and the proposed design will be installed on exist steel structure. The effect of reducing the height of the inner wall will be calculated below: 


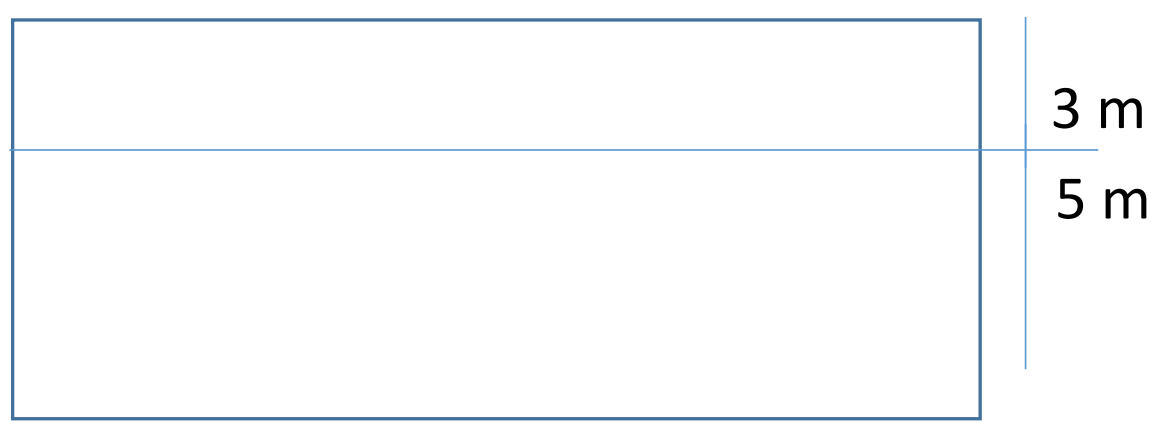

Figure 10. Schematic diagram for height of ceiling roof.

\section{Walls Calculation}

(The height now is 5 meter instead of 8 meter)

\section{South wall calculation}

$\mathrm{U}=\frac{1}{R_{t}}, \mathrm{R}=\frac{L}{k}, R_{t}=R_{1}+R_{2}+R_{3}+\cdots$

$R_{t}=R_{1}+R_{2}+R_{3}$

$R_{t}=\frac{0.2}{1.72}+\frac{0.004}{0.71}+\frac{0.001}{0.128}=0.458 \mathrm{~m}^{2} \mathrm{~K} / \mathrm{W}$

$U_{t}=\frac{1}{0.458}=2.184 \mathrm{~W} / \mathrm{m}^{2} \mathrm{~K}$

A $=$ length $\mathrm{x}$ high $=88 \times 5=440 \mathrm{~m}^{2}$

$Q_{\text {South Wall }}=\mathrm{A} * \mathrm{U} * \Delta \mathrm{t}$

$Q_{\text {South Wall }}=440 \times 2.184 \times(43-23)=19.22 \mathrm{KW}$

\section{East wall calculation}

$R_{t}=\frac{0.2}{1.72}+\frac{0.004}{0.71}+\frac{0.001}{0.128}=0.458 \mathrm{~m}^{2} \mathrm{~K} / \mathrm{W}$

$U_{t}=\frac{1}{0.458}=2.184 \mathrm{~W} / \mathrm{m}^{2} \mathrm{~K}$

$\mathrm{A}=$ length $\mathrm{x}$ high $=(43 \times 5)+(15 \times 5)=290 \mathrm{~m}^{2}$

$Q_{\text {East Wall }}=\mathrm{A} * \mathrm{U} * \Delta \mathrm{t}$

$Q_{\text {East Wall }}=290 \times 2.184 \times(43-23)=12.67 \mathrm{KW}$

\section{West wall calculation}

$R_{t}=\frac{0.2}{1.72}+\frac{0.004}{0.71}+\frac{0.001}{0.128}=0.458 m^{2} \mathrm{~K} / \mathrm{W}$

$U_{t}=\frac{1}{0.458}=2.184 \mathrm{~W} / \mathrm{m}^{2} \mathrm{~K}$ 
A = length $\mathrm{x}$ high $=58 \times 5=290 \mathrm{~m}^{2}$

$Q_{\text {West Wall }}=\mathrm{A} * \mathrm{U} * \Delta \mathrm{t}$

$Q_{\text {West Wall }}=290 \times 2.184 \times(43-23)=12.67 \mathrm{KW}$

\section{North wall calculation}

$R_{t}=\frac{0.2}{1.72}+\frac{0.004}{0.71}+\frac{0.001}{0.128}=0.458 \mathrm{~m}^{2} \mathrm{~K} / \mathrm{W}$

$U_{t}=\frac{1}{0.458}=2.184 \mathrm{~W} / \mathrm{m}^{2} \mathrm{~K}$

A = length $\mathrm{x}$ high $=88 \times 5=440 \mathrm{~m}^{2}$

$Q_{\text {North Wall }}=\mathrm{A} * \mathrm{U} * \Delta \mathrm{t}$

$Q_{\text {North Wall }}=440 \times 2.184 \times(43-23)=19.2 \mathrm{KW}$

Table 8. Comparison between walls heat gain before and after reducing the height

\begin{tabular}{|c|c|c|c|}
\hline Direction & Wall load & $\begin{array}{c}\text { Load before } \\
\text { reducing the } \\
\text { height (KW) }\end{array}$ & $\begin{array}{c}\text { Load after } \\
\text { reducing the } \\
\text { height (KW) }\end{array}$ \\
\hline South & $Q_{S}$ & 30.75 & 19.22 \\
\hline East & $Q_{E}$ & 20.27 & 12.67 \\
\hline West & $Q_{W}$ & 20.27 & 12.67 \\
\hline North & $Q_{N}$ & 30.75 & 19.22 \\
\hline Total & $Q_{\text {Total walls }}$ & 102.04 & 63.78 \\
\hline
\end{tabular}

\section{Improve the insulation of walls and roof:}

Insulation materials one of the tools used to reduce heat gain from the walls and roofs as there are many studies about improving these materials. A culture of rationalization of energy consumption, or the so-called energy management is a concept that must be present during designing the buildings and facilities and since the 25 years which is the age of the local factory, the walls are not built of insulating bricks as shown in Figure 5 where the common bricks were used and this type was widely used at that time.

Polystyrene insulation material was installed on the roof as shown 6 but through the time eroded the insulating material and no longer give the desired result. In addition, the availability of better insulating materials in the market gave us more options and according to that another material selected which is Stone Wool insulation where its insulation is better than Polystyrene because its thermal conductivity coefficient is lower $(\mathrm{K} \mathrm{S}=0.02 \mathrm{~W} / \mathrm{km}<\mathrm{K} \mathrm{P}=0.045 \mathrm{~W} / \mathrm{km}$ ) as shown in Figure 6 and 12. In the next step, the heat gain will be calculated after the improvements and the results will be compared to the heat gain results before the improvements to ensure the feasibility and effectiveness of these improvements. 


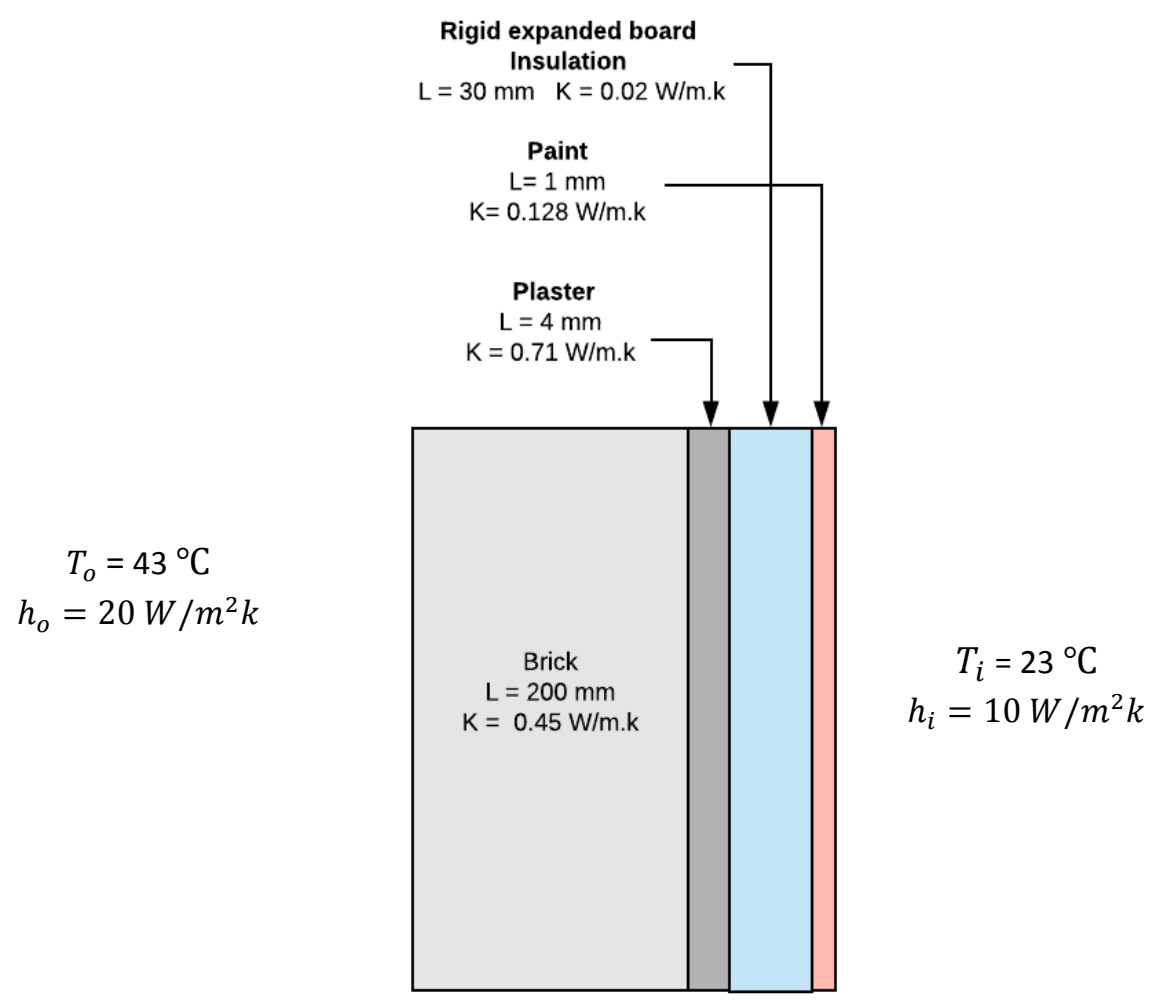

Figure 11. Schematic diagram for wall components with insulation material.

\section{South wall calculation}

$\mathrm{U}=\frac{1}{R_{t}}, \mathrm{R}=\frac{L}{k}, R_{t}=R_{1}+R_{2}+R_{3}+\cdots$

$R_{t}=R_{1}+R_{2}+R_{3}$

$R_{t}=\frac{0.2}{1.72}+\frac{0.004}{0.71}+\frac{0.001}{0.128}+\frac{0.02}{0.045}=0.57 \mathrm{~m}^{2} \mathrm{~K} / \mathrm{W}$

$U_{t}=\frac{1}{0.57}=1.742 \mathrm{~W} / \mathrm{m}^{2} \mathrm{~K}$

A = length $\mathrm{x}$ high $=88 \times 5=440 \mathrm{~m}^{2}$

$Q_{\text {South Wall }}=\mathrm{A} * \mathrm{U} * \Delta \mathrm{t}$

$Q_{\text {South Wall }}=440 \times 1.742 \times(43-23)=15.3 \mathrm{KW}$

\section{East wall calculation}

$R_{t}=\frac{0.2}{1.72}+\frac{0.004}{0.71}+\frac{0.001}{0.128}+\frac{0.02}{0.045}=0.57 \mathrm{~m}^{2} \mathrm{~K} / \mathrm{W}$

$U_{t}=\frac{1}{0.57}=1.742 \mathrm{~W} / \mathrm{m}^{2} \mathrm{~K}$

$A=$ length $\mathrm{x}$ high $=(43 \times 5)+(15 \times 5)=290 \mathrm{~m}^{2}$

$Q_{\text {East Wall }}=\mathrm{A} * \mathrm{U} * \Delta \mathrm{t}$ 
$Q_{\text {East Wall }}=290 \times 1.742 \times(43-23)=10.1 \mathrm{KW}$

\section{West wall calculation}

$R_{t}=\frac{0.2}{1.72}+\frac{0.004}{0.71}+\frac{0.001}{0.128}+\frac{0.02}{0.045}=0.57 \mathrm{~m}^{2} \mathrm{~K} / \mathrm{W}$

$U_{t}=\frac{1}{0.57}=1.742 \mathrm{~W} / \mathrm{m}^{2} \mathrm{~K}$

$\mathrm{A}=$ length $\mathrm{x}$ high $=58 \times 5=290 \mathrm{~m}^{2}$

$Q_{\text {West Wall }}=\mathrm{A} * \mathrm{U} * \Delta \mathrm{t}$

$Q_{\text {West Wall }}=290 \times 1.742 \times(43-23)=10.1 \mathrm{KW}$

\section{North wall calculation}

$R_{t}=\frac{0.2}{1.72}+\frac{0.004}{0.71}+\frac{0.001}{0.128}+\frac{0.02}{0.045}=0.57 \mathrm{~m}^{2} \mathrm{~K} / \mathrm{W}$

$U_{t}=\frac{1}{0.57}=1.742 \mathrm{~W} / \mathrm{m}^{2} \mathrm{~K}$

A = length $\mathrm{x}$ high $=88 \times 5=440 \mathrm{~m}^{2}$

$Q_{\text {North Wall }}=\mathrm{A} * \mathrm{U} * \Delta \mathrm{t}$

$Q_{\text {North Wall }}=440 \times 1.742 \times(43-23)=15.3 \mathrm{KW}$

\section{Roof calculation}

$$
\begin{gathered}
T_{o}=43^{\circ} \mathrm{C} \\
h_{o}=20 \mathrm{~W} / \mathrm{m}^{2} k
\end{gathered}
$$

\begin{tabular}{|c|}
\hline Galvanized Iron $\mathrm{L}=1 \mathrm{~mm} \quad \mathrm{~K}=60 \mathrm{~W} / \mathrm{m} . \mathrm{k}$ \\
\hline $\begin{array}{c}\text { Stone Wool Insulation } \\
\mathrm{L}=30 \mathrm{~mm} \quad \mathrm{~K}=0.02 \mathrm{~W} / \mathrm{m} . \mathrm{k}\end{array}$ \\
\hline Air $\mathrm{L}=3000 \mathrm{~mm} \quad \mathrm{~K}=0.024 \mathrm{~W} / \mathrm{m} . \mathrm{K}$ \\
\hline Gypsum board $\mathrm{L}=15 \mathrm{~mm} \mathrm{~K} \quad \mathrm{~K}=0.17$ \\
\hline
\end{tabular}

$$
\begin{gathered}
T_{i}=23^{\circ} \mathrm{C} \\
h_{i}=10 \mathrm{~W} / \mathrm{m}^{2} k
\end{gathered}
$$

Figure 12. Schematic diagram for Areas $1 \& 3$ roof components with new insulation 


$$
\begin{gathered}
T_{o}=43^{\circ} \mathrm{C} \\
h_{o}=20 \mathrm{~W} / \mathrm{m}^{2} \mathrm{k}
\end{gathered}
$$

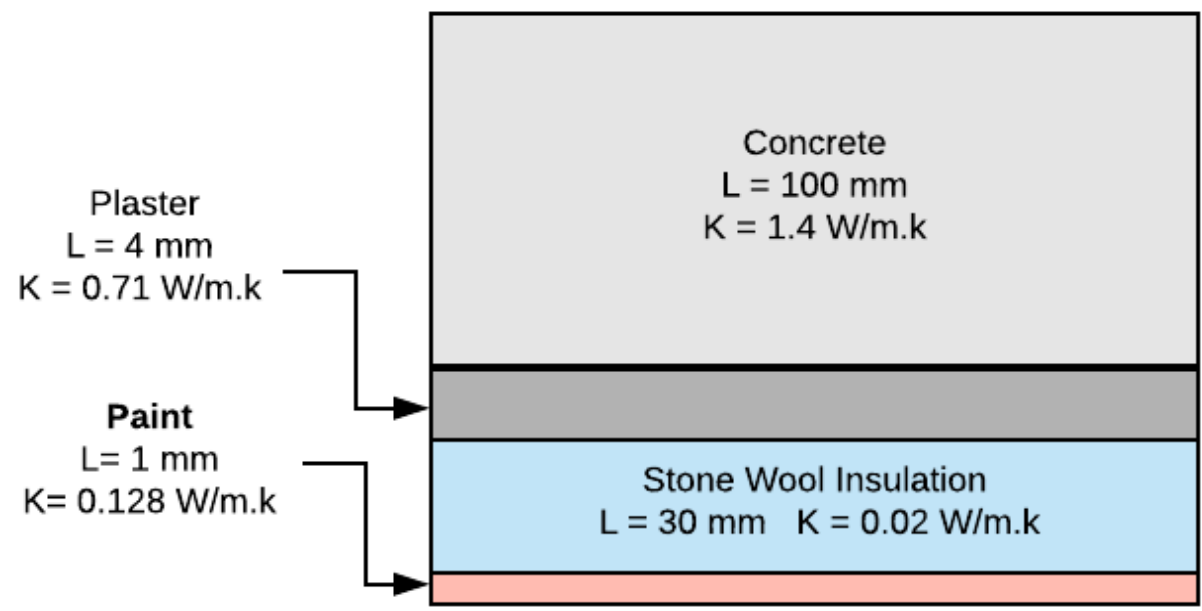

Figure 13. Schematic diagram for Areas 2 roof components with new insulation.

$\mathrm{U}=\frac{1}{R_{t}}, \mathrm{R}=\frac{L}{k}, \frac{1}{R_{1,2,3}}=\frac{1}{R_{1}}+\frac{1}{R_{2}}+\frac{1}{R_{3}}, R_{t}=R_{o}+R_{1,2,3}+R_{i}$

$R_{\text {Area } 1,3}=R_{1}+R_{2}+R_{3}+R_{4}=\frac{0.001}{60}+\frac{0.03}{0.02}+\frac{0.015}{0.17}+\frac{3}{0.024}=123.8 \mathrm{~m}^{2} \mathrm{~K} / \mathrm{W}$

$R_{\text {Area } 2}=R_{1}+R_{2}+R_{3}+R_{4}=\frac{0.100}{1.4}+\frac{0.004}{0.71}+\frac{0.03}{0.02}+\frac{0.001}{0.13}=1.335 \mathrm{~m}^{2} \mathrm{~K} / \mathrm{W}$

$\frac{1}{R_{\text {Area } 1,2,3}}=\frac{1}{123.8}+\frac{1}{1.335}+\frac{1}{123.8}=0.765 \mathrm{~K} / \mathrm{W}, R_{\text {Area } 1,2,3}=\frac{1}{0.765}=1.31 \mathrm{~m}^{2} \mathrm{~K} / \mathrm{W}$

$R_{t}=\frac{1}{20}+1.31+\frac{1}{10}=1.457 \mathrm{~m}^{2} \mathrm{~K} / \mathrm{W}$

$U_{t}=\frac{1}{1.457}=0.686 \mathrm{~W} / \mathrm{m}^{2} \mathrm{~K}$

$A=$ length $*$ high $=[(58 \times 40)+(10 \times 43)+(38 \times 43)]=4384 \mathrm{~m}^{2}$

$Q_{R}=\mathrm{A} * \mathrm{U} * \Delta \mathrm{t}=4384 \times 0.686 \times(43-23)=60.177 \mathrm{KW}$

Total external heat gain:

$Q_{\text {External heat gain }}=Q_{\text {South }}+Q_{\text {East }}+Q_{\text {West }}+Q_{\text {North }}+Q_{\text {Roof }}$

$Q_{\text {External heat gain }}=15.3+10.1+10.1+15.3+60.177=111 \mathrm{~kW}$ 
Budapest International Research in Exact Sciences (BirEx) Journal

Volume 1, No 4, October 2019, Page:25-44 e-ISSN: 2655-7827 (Online), p-ISSN: 2655-7835 (Print) www.bircu-journal.com/index.php/birex emails: birex.journal@gmail.com birex.journal.qa@gmail.com

Table 9. Loads of all four walls and roof before and after improvement

\begin{tabular}{|c|c|c|c|c|c|c|c|}
\hline Direction & $\begin{array}{c}\text { Wall } \\
\text { load }\end{array}$ & $\begin{array}{c}\text { Load } \\
\text { before } \\
\text { reducing } \\
\text { the height } \\
(\mathrm{KW})\end{array}$ & $\begin{array}{c}\text { Load after } \\
\text { reducing } \\
\text { the height } \\
(\mathrm{KW})\end{array}$ & $\begin{array}{c}\text { Load after reducing } \\
\text { the height and install } \\
\text { the insulation material } \\
(\mathrm{KW})\end{array}$ & $\begin{array}{c}\text { Reducing } \\
\text { the wall } \\
\text { area } \\
\text { improve } \\
\text { ment \% }\end{array}$ & $\begin{array}{c}\text { Improve } \\
\text { Insulation } \\
\text { material } \\
\%\end{array}$ & $\begin{array}{c}\text { Total } \\
\text { Improve } \\
\text { ment \% }\end{array}$ \\
\hline South & $Q_{S}$ & 30.75 & 19.22 & 15.3 & 37.5 & 20.4 & 50.2 \\
\hline East & $Q_{E}$ & 20.27 & 12.67 & 10.1 & 37.5 & 20.3 & 50.2 \\
\hline West & $Q_{W}$ & 20.27 & 12.67 & 10.1 & 37.5 & 20.3 & 50.2 \\
\hline North & $Q_{N}$ & 30.75 & 19.22 & 15.3 & 37.5 & 20.4 & 50.2 \\
\hline Roof & $Q_{R}$ & 412.45 & 412.45 & 60.2 & 0.0 & 85.4 & 85.4 \\
\hline Total & $Q_{\text {Tota }}$ & 514.49 & 476.23 & 111 & 7.4 & 76.7 & 78.4 \\
\hline
\end{tabular}

\section{Total heat gain (External and Internal)}

$Q_{\text {Total heat gain }}=Q_{\text {External heat gain }}+Q_{\text {Internal heat gain }}=1659.5 \mathrm{KW}$

Table 10. Comparison between heat gain before and after improving

\begin{tabular}{|c|c|c|c|}
\hline Item & Internal & External & Total Heat gain \\
\hline Before improving & 1145 & 514.5 & 1659.5 \\
\hline After improving & 1122.6 & 111 & 1233.6 \\
\hline Improving \% & $2 \%$ & $78.40 \%$ & $25.70 \%$ \\
\hline
\end{tabular}

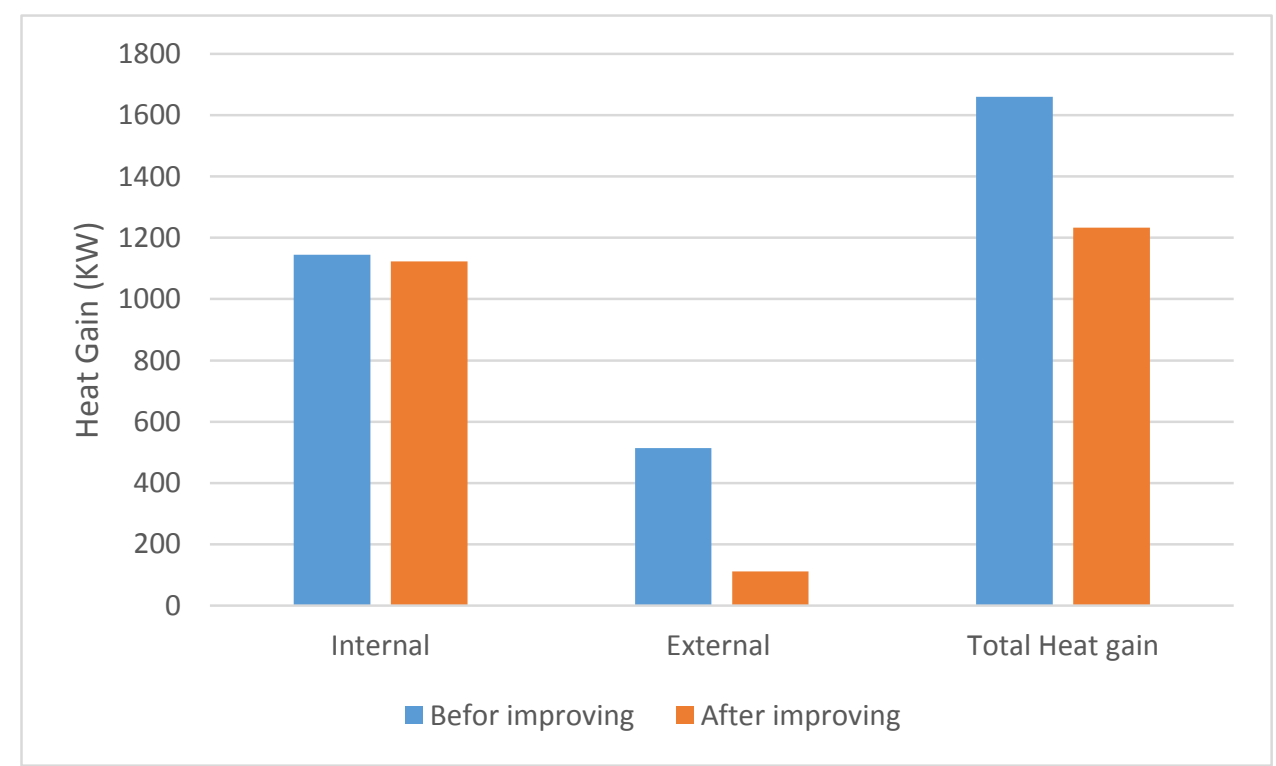

Figure 14. Comparison between heat gain before and after improving. 


\section{Conclusion}

The study evaluated the current status of the cooling system in the local factory where it has 24 units with a capacity of 260 tons (table 2), but nine of them do not work (Table 3 ) and the rest do not give the required capacity as cooling system (Table 1 and Picture 1). The question is whether in case of repairing the 24 units, are they sufficient to cool the factory at the required level? To answer this question, the internal and external heat gain was calculated and compared them with the capacity of the current cooling system and the result was a deficit of $45 \%$ of cooling capacity where the total calculated heat gain is 472 tons while the current capacity is 260 tons only. The answer to the question is that the current system cannot cover the entire factory, so the capacity of the cooling system should be increased according to the calculation.

The aim of the study is not to design a cooling system for the local factory but rather to focus on one aspect of the design which is cooling loads. The study aimed to improve the cooling system by reducing the internal and external heat gain source like heat gain from people, lighting, equipment walls and roof where the percentage of internal heat gain before the improvement is about $1145 \mathrm{~kW}$ and the external heat gain before the improvement is approximately $415 \mathrm{~kW}$ and the total heat loads $1659.5 \mathrm{~kW}$, which is equivalent to 472 tons of refrigeration.

The idea of improvement relies on the principle of the use of engineering concepts related to heat transfer and apply them in the case where the local factory focused on improvements that do not cause a significant change in the structure of the factory and affect production lines. The improvements were based on three points: reducing lighting heat gain by replacing fluorescent bulbs with energy-saving LED bulbs. Also, reduce the size of the cooling space by installing the ceiling of gypsum board at a height of 5 meters of the ground instead of 8 meters as shown in Figure 10. The last point is improving insulation using insulation materials with a lower thermal conductivity and available on the local the market.

In the local factory, there are about 835 fluorescent bulbs and produce about $36 \mathrm{~kW}$ heat gained and the alternative solution is LED bulb. Although they give the same light intensity, they produce $64 \%$ less heat as they produce only $13 \mathrm{~kW}$ for the same number of bulbs. This improvement did not significantly reduce internal heat gain as it reduced only $2 \%$ of them as shown in Table 6 and also Figure 14.

The second point is to reduce the size of cooling space or in other words reduce the area of the internal walls of production zones where the height decreased from 8 to 5 meters and the heat gained from the walls before reducing the height is about $102 \mathrm{~kW}$ and after reducing the height is about $63.78 \mathrm{~kW}$ which means the heat gain was reduced by $37.4 \%$ as shown in table 7 .

The third point is to improve the material insulation of walls and roof where polystyrene is used in the rood currently and its thermal conductivity is (0.045) and that the proposed material is rock wool (Fig. $12 \& 13$ ) and its thermal conductivity (0.02) and when the material has less the thermal conductivity that means it is more insulation. In spite of the heat gained from the roof drop dramatically by $85 \%$ the heat gain reduced $20.3 \%$ after the addition of heat insulating material in the walls after using the material Rigid expanded board as in Figure 11. After applying the improvements, it was found that its effect on reducing the internal heat gain is about $2 \%$ and its effect on reducing the external heat $78 \%$, which constitutes a decrease of 
the total heat gain by about $25 \%$ as shown in table 9 and this ratio is considered effective and achieved the required results from the research.

\section{Recommendations}

The improvements that have been applied to the cooling system are not considered final improvements as there could be further improvements affecting the amount of heat gained from the factory, especially the internal heat gain where there are factors that may affect the required cooling capacity such as ventilation. Ventilation is an important factor that must be taken into account when calculating the cooling capacity required for the factory as the air coming out of the factory is cold and the air entering is hot which increases the heat gained in place. Isolate machines with high heat gained and shown in figure 3 and re-design of air distribution (table 2) inside the factory building on the whereabouts of the workers and these and others improvements that can be applied in other studies.

\section{References}

ASHRAE. (2019). Climatic Design Conditions. Available at: http://ashrae-meteo.info/ (Accessed at: 5/06/19).

Bhatia, A. (2001). Cooling load calculations and principles. Continuing Education and Development, Inc. New York, 877.

Cengel, Y., Boles, M. (2007). Thermodynamics: An Engineering Approach. McGrow-Hill, Higher education, 6th Edition.

Janna, W. (2013). Design of Fluid Thermal Systems. Cengage Learning Center, US. 4th edition.

Mcquiston, F., Parker, J. \& Spitler, J. (2005). Heating, Ventilating and Air conditioning: Analysis and Design. John Wiley \& sons, Inc. 6th Edition.

The National optical astronomy observatory NOAO. (2019). Types of lights. Available at: https://www.noao.edu/education/QLTkit/ACTIVITY_Documents/Energy/TypesofLight s.pdf (Accessed at: 18/08/19). 